\title{
The influence of changes in viticulture management on the butterfly (Lepidoptera) diversity in a wine growing region of southwestern Germany
}

\author{
Thomas SCHMITT, Bettina AUGENSTEIN and Aline FINGER
}

\author{
Biogeographie, Fachbereich VI, Wissenschaftspark Trier-Petrisberg, Universität Trier, D-54286 Trier, Germany; \\ e-mail: thsh@uni-trier.de
}

\begin{abstract}
Key words. Conservation measures, dispersal ability, diversity indices, Lepidoptera, Rhineland-Palatinate, succession, transect counts, vineyards
\end{abstract}

\begin{abstract}
Viticulture is one of the most intensively managed agricultural ecosystems in Europe. Therefore, the conservation problems of vineyards and the ecological benefits of increasing the amount of fallow land are addressed using butterflies as a model group. We established 43 transects, each $100 \mathrm{~m}$ long, in a vineyard region in the vicinity of Trier (Rhineland-Palatinate, Germany) and recorded the butterflies observed along these transects on 20 occasions from late May to early August 2003. Transects crossed vineyards, fallow land and transitional areas of land. 4041 individuals of 34 species showed the typical pattern of relative abundance with few common and many relatively rare species. Fallow land had more individuals and species and a higher Shannon species diversity index than vineyards. Community evenness and average butterfly dispersal ability were highest in the vineyards. Principal Factor Analyses and UPGMA cluster analysis distinguished between fallow land and vineyards. The difference between early meadow and late forest fallow land areas was not strong, but the former tended to have a higher diversity than the latter. Vineyards thus might act as a sink for butterflies. Therefore, a clear separation between vineyards and fallow land is best for nature conservation. As young fallow land tends to have a higher diversity than older fallow land in this study, it is likely that the conservation value of vineyards for butterflies could be increased by active management of fallow land areas.
\end{abstract}

\section{INTRODUCTION}

The natural vegetation in most of Central Europe during the Holocene consisted of various types of deciduous beech forests, interspersed with smaller areas of other forest types (e.g. at very moist localities or on steep rocky slopes) (Pott, 1995). Prior to human activity, Central Europe, therefore, was almost completely forested with very few climatically and orographically determined non-forested areas (Weidemann, 1986; Pott, 1995; Varga, 2003a; but see e.g. Gerken \& Görner, 2001). Human activities resulted in the transformation of primary forests into pastures, meadows and arable land (Weidemann, 1986; Varga, 2003a).

It is well known that the species composition of the European deciduous forests is very different from that of non-forested areas, and the species-richness of the latter is higher than of the former for several species groups, e.g. butterflies (e.g. Erhardt, 1985a; Weidemann, 1986; Ebert \& Rennwald, 1991; Varga, 2003a). The destruction of the forests by humans and the creation of grasslands by grazing or mowing resulted in an increase in populations of species expanding their geographic ranges from the southern European forest-steppes or eastern steppe areas over the last few hundreds of years (Malicki, 1970; Varga, 2003a, b). This process gave rise to a man-made landscape particularly rich in species due to landscape diversity (WallisDeVries et al., 2002; Varga, 2003b), and some of these man-made habitats are among the most species rich habitats in temperate regions, such as seminatural calcareous grasslands (van Swaay, 2002;
WallisDeVries et al., 2002), and form an important part of Europe's natural heritage (Schmitt \& Rákosy, 2007).

However, species diversity began to decline over much of Central Europe after the onset of "modern" agriculture following the Second World War (Warren, 1993; van Swaay \& Warren, 1999; Thomas et al., 2004). This was mostly due to (i) the use of chemical fertilizers, which transformed most of the nutrient poor grasslands into nutrient rich highly productive grasslands of low species diversity, (ii) the intensive use of different types of pesticides, which also damage non-target organisms and (iii) realignment of field margins resulting in much larger average field sizes and a strong reduction in structural landscape diversity (van Swaay \& Warren, 1999; SteffanDewenter \& Tscharntke, 2002; Tscharntke et al., 2002; Benton et al., 2003; Hole et al., 2005; Rundlöf \& Smith, 2006; Öckinger \& Smith, 2007a).

Viticulture is one of the most intensively managed agricultural ecosystems: (i) agri-industrial vineyards are among the most heavily treated areas in terms of fertilizers and pesticides and (ii) most of the ecologically valuable structures (e.g. old stonewalls and small unproductive patches) were destroyed by field realignments. However, the retraction of viticulture from many steep slopes that are costly to cultivate resulted in an increase in the amount of fallow land in modern vineyards.

To address the conservation problems and challenges within Central European vineyards, we selected butterflies as model group (cf. Pollard \& Yates, 1993; Thomas \& Morris, 1994; Schmitt \& Rákosy, 2007) and counted 
them along transects across vineyards, which included fallow land. The fallow land consists of areas of abandoned vineyards that have become overgrown with flowering weeds and as a consequence of succession bushes and small trees. The meadow-like areas are occasionally grazed by sheep, which might have slowed down the process of succession. This design allows us to address the following questions: Do vineyards harbour fewer species of butterflies than fallow land, and the vineyard margins an intermediate number? Is it likely that vineyards act as sinks for butterflies coming in from adjacent habitats? Is, therefore, the average dispersal ability of the species in the vineyards higher than that of those species recorded in the fallow land? What conservation measures are necessary to maintain maximum biodiversity in a vineyard-fallow land mosaic landscape?

\section{MATERIAL AND METHODS}

This study was performed in the "Aveler Tal", a valley with intensive viticulture (i.e. vineyards were regularly treated with pesticides) at the edge of the city of Trier (Moselle valley, western Rhineland-Palatinate, southwestern Germany). We selected a total of 43 transects, each about $100 \mathrm{~m}$ long and located on three adjoining southwest-facing slopes (steepness of all slopes 20 to $30 \%$ ). One slope was entirely fallow land, the second predominantly vineyards but with fallow land extending as a strip across the upper third of the slope and the third a mosaic of vineyards and fallow land. In many cases, the end of one transect was the beginning of the following one; the lateral distance between two transect tracks was at least $100 \mathrm{~m}$. Transects were located within vineyards, i.e. viticulture with bare ground or little herbaceous vegetation (7), at the margin of vineyards, i.e. vineyard on one side of the track and fallow land on the other (11) or on fallow land (25). The bare ground in vineyards is maintained by mechanical measures or application of herbicides. Five different types of fallow land were distinguished: (i) grassland with high growing vegetation (mostly $>50$ $\mathrm{cm}$ in July), (ii) grassland as in (i), but with some interspersed bushes (height $<2.5 \mathrm{~m}$ ), (iii) bushes and hedges (height $>2.5$ $\mathrm{m})$ with little open grassland, (iv) sunny herb- and hedge-rich early forest stages (height $>5 \mathrm{~m}$ ), and (v) secondary forest. For reasons of simplicity and statistics (i.e. to archive adequate numbers of samples in each group), (i) and (ii) are pooled as "meadow fallow land" and (iii) to (v) as "forest fallow land". Of the 25 fallow land transects, four were located in meadow fallow land, ten in forest fallow land and eleven had meadow fallow land on one side and forest fallow land on the other side of the track.

The resources for larvae and adult butterflies were very limited in the vineyards as plants were quite scarce, and only a few plant species were present; there were generally few flowers or they were non-existent. The larval food resources on the fallow land were abundant as vegetation covered most of the ground along the fallow land transects. However, the fallow land areas of type (i) and (ii) supported mostly or exclusively herbaceous plants and types (iii) to (v) mostly woody plants. Suitable butterfly flowers (e.g. Asteraceae, Dipsacaceae, Leguminosae, some Rosaceae) were abundant along all the "meadow fallow land" transects; fewer species and individual suitable nectar sources were present along the "forest fallow land" transects, and were more patchily distributed, e.g. large flowering Rubus fruticosus agg. shrubs interspersed with sections of the transect where butterfly flowers were rare.
All transects followed existing tracks; all butterflies occurring in a strip 2.5 wide on each side of the track were counted (cf. Pollard \& Yates, 1993; Settele et al., 2005). If necessary, butterflies were netted for determination and then released. Two people counted the butterflies, i.e. one person on each side of the track. Data were recorded by a third person.

All transects were sampled 20 times (about twice a week) during spring and summer 2003 starting 29.v.2003 and ending 7.viii.2003. Each complete sample included the results from all the transects, which were sampled on the same day; if it was not possible to complete the sampling on one day it was continued the following day. All data not fulfilling this criterion were discarded. Fieldwork was conducted between 10 am and 5 pm when weather conditions were fine (sunny; no or little wind; > $17^{\circ} \mathrm{C}$ ) so that the results were comparable for all transects (cf. Erhardt, 1985a; Pollard \& Yates, 1993; Settele et al., 1999). Transect counts were started at different times of the day so that each transect was visited at different times of the day.

A matrix containing the total numbers of individuals per species recorded along each transect at all 20 transect counts was constructed. Based on this database, different diversity parameters $\left(S_{\mathrm{H}}\right.$ : Shannon species diversity index based on $\log _{10} ; E_{\mathrm{S}}$ : Community Evenness based on the $\log _{10}$ Shannon Index; $\alpha$ : alpha species diversity) were calculated using the BioDiversity Professional Beta software (Lambshead et al., 1997). The average dispersal ability of each of the species observed along each transect was calculated based on the scale of Bink (1992) ranging from 1 (very sedentary species) to 9 (migratory species). The means and standard deviations were calculated considering each individual as one independent unit. STATISTICA was used for the calculation of Kruskal-Wallis ANOVAs for testing differences among groups and $\mathrm{U}$ tests for a posteriori tests between pairs of groups, and the construction of UPGMA cluster analysis based on Manhattan distances, and calculation of Principal Factor Analyses (PFA) using the maximum likelihood factor method and the varimax normalised factor rotation.

The nomenclature of Karsholt \& Razowski (1996) was applied. As it is not possible to distinguish between Leptidea sinapis and $L$. reali in the field, this sibling species complex was treated as one morpho-species in the analysis.

\section{RESULTS}

A total of 4,041 individuals belonging to 34 butterfly species was recorded (Fig. 1; complete data are available from the corresponding author on request). Nine species are listed in the Red Data Book of the RhinelandPalatinate (Bläsius et al., 1987) and eight in the Red Data Book of Germany (Pretscher, 1998), but none in the European Red Data Book (van Swaay \& Warren, 1999). No species listed in the annexes of the Habitat Directive of the European Union was observed. The individuals were unevenly distributed among species showing the typical pattern of relative abundance (i.e. a few very common species and many relatively rare species; Fig. 1). Thus, over $75 \%$ of all individuals belonged to the six most common species (i.e. Maniola jurtina: $34.7 \%$, Pieris rapae: $10.8 \%$, Coenonympha pamphilus: 9.6\%, Melanargia galathea: 9.4\%, Aphantopus hyperantus: 7.0\%, Pyronia tithonus: $5.8 \%$ ) and $59 \%$ of all species made up just $5 \%$ of the total number of individuals.

Species numbers and numbers of individuals were highest on fallow land and lowest in vineyards with intermediate numbers for vineyard margins (both ANOVAs: $p$ 


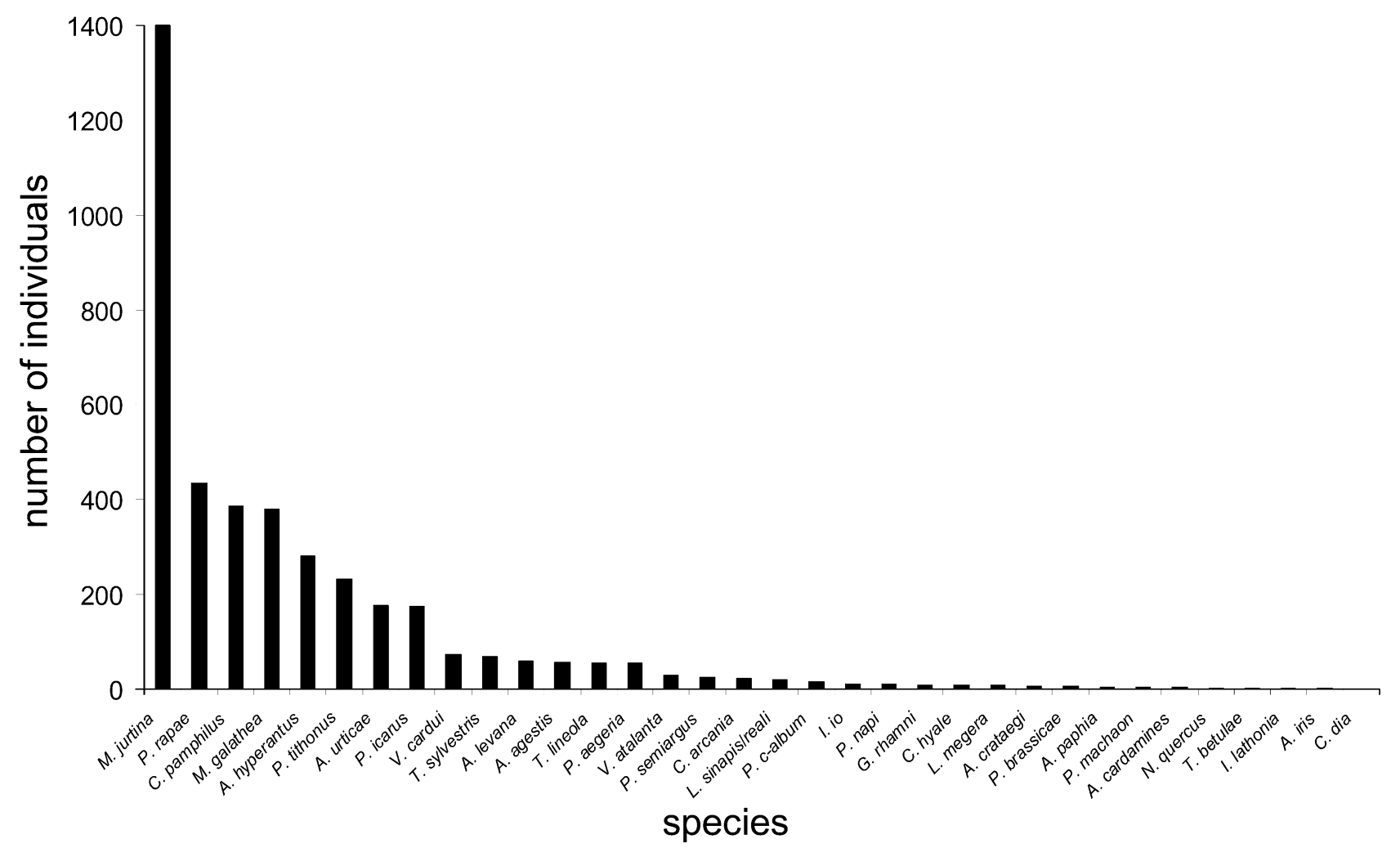

Fig. 1. Relative abundance of the 34 butterfly species recorded along 43 transects across a vineyard-fallow land mosaic landscape in the vicinity of Trier (Germany) on a total of 20 occasions over the period late May to early August 2003.

$<0.001$; Table 1). The diversity parameters have large ranges: mean Alpha $(\alpha): 3.94( \pm 1.59 \mathrm{sd})$ ranging from 0.58 to 8.20 ; mean Shannon Index $\left(S_{\mathrm{H}}\right): 0.785( \pm 0.170$ $\mathrm{sd})$ ranging from 0.151 to 1.094 ; mean Evenness $\left(E_{\mathrm{S}}\right)$ : $0.778( \pm 0.093 \mathrm{sd})$ from 0.502 to 0.938 . $S_{\mathrm{H}}$ and $E_{\mathrm{S}}$ differed significantly between vineyards, vineyard margins and fallow land (ANOVAs: $p=0.041$ and $<0.001$, respectively; Table 1 ). The mean dispersal ability of butterflies recorded on fallow land (mean: $4.31 \pm 0.59$ ranging from 3.60 to 6.14 ) was the lowest, in vineyards the highest and vineyard margins had an intermediate level (ANOVA: $p=0.001$; Table 1). Vineyard margins differed as often significantly from fallow land as from vineyards ( 3 parameters each). Vineyards and fallow land differed significantly for all parameters (apart from Alpha).
Cluster Analysis (not shown) and Principal Factor Analysis (Fig. 2a) both separated vineyard transects from fallow land transects; the latter placed the vineyard margin transects between the vineyards and the fallow land areas, showing its intermediate position. The first two axes of the PFA explained some $67.6 \%$ of the total variance.

Meadow fallow land transects and forest fallow land transects did not differ as strongly in number of individuals and species, diversity indices or species dispersal ability as vineyards and fallow land in general; however, the meadow fallow land areas tended to be more diverse than the forest fallow land areas (Table 2). Both fallow land types were segregated by a PFA (Fig. 2b) with the first two axes explaining some $79.6 \%$ of the total variance. Mixed fallow land transects (i.e. with meadow

TABLE 1. Means of species and individuals per transect, Shannon index $\left(S_{\mathrm{H}}\right)$, Alpha diversity $(\alpha)$, Evenness $\left(E_{\mathrm{S}}\right)$ and species dispersal ability (Bink, 1992) for vineyards, vineyard margins and fallow land in a vineyard-fallow land mosaic landscape in the vicinity of Trier (Germany). All means are given with their standard deviation. $p$ values refer to Kruskal-Wallis ANOVAs. A posteriori tests for significant differences between pairs of groups are calculated using $U$ tests; different letters after the respective values indicate significant differences $(p<0.05)$.

\begin{tabular}{lcccr}
\hline & vineyard & vineyard margin & fallow land & $p$ \\
\hline Species & $5.86 \pm 1.86^{\mathrm{a}}$ & $10.64 \pm 3.72^{\mathrm{b}}$ & $13.24 \pm 4.55^{\mathrm{b}}$ & 0.0005 \\
Individuals & $15.0 \pm 8.6^{\mathrm{a}}$ & $60.7 \pm 24.4^{\mathrm{b}}$ & $130.7 \pm 60.0^{\mathrm{c}}$ & $<0.0001$ \\
$S_{\mathrm{H}}$ & $0.662 \pm 0.119^{\mathrm{a}}$ & $0.818 \pm 0.144^{\mathrm{b}}$ & $0.806 \pm 0.181^{\mathrm{b}}$ & 0.0409 \\
$\alpha$ & $3.95 \pm 0.98^{\mathrm{a}}$ & $4.17 \pm 2.05^{\mathrm{a}}$ & $3.84 \pm 1.55^{\mathrm{a}}$ & 0.8547 \\
$E_{\mathrm{S}}$ & $0.884 \pm 0.044^{\mathrm{a}}$ & $0.810 \pm 0.079^{\mathrm{a}}$ & $0.734 \pm 0.080^{\mathrm{b}}$ & 0.0003 \\
Dispersal & $4.92 \pm 0.82^{\mathrm{a}}$ & $4.62 \pm 0.56^{\mathrm{a}}$ & $4.01 \pm 0.24^{\mathrm{b}}$ & 0.0011 \\
\hline
\end{tabular}



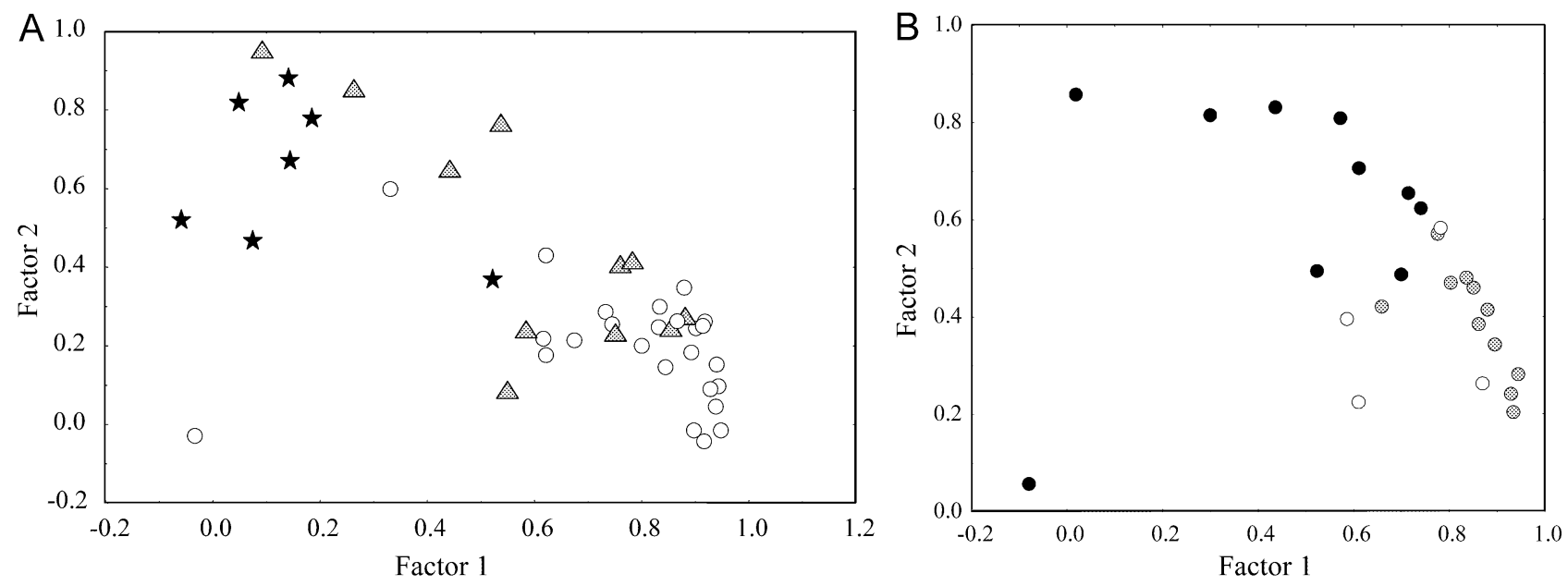

Fig. 2. Principal Factor Analysis (PFA) (maximum likelihood factor method, varimax factor rotation) based on the butterfly assemblages recorded along 43 transects in a vineyard-fallow land mosaic landscape in the vicinity of Trier (Germany) on a total of 20 occasions from late May to early August 2003. A - PFA based on the results for all 43 transects, explained variance: Factor 1: 49.5\%, Factor 2: 18.1\%; symbols: white circle: fallow land; grey triangle: vineyard margin, black star: vineyard; B - PFA based on the results of 25 transects across fallow land, explained variance: Factor 1: 51.8\%, Factor 2: 27.8\%; symbols: white circle: meadow fallow land; black circle: forest fallow land; grey circle: meadow fallow land on one and forest fallow land on the other side of the transect.

fallow land on one side and forest fallow land on the other side of the track) were similar to meadow fallow land areas. Furthermore, some species were exclusively found on one of the two types of fallow land (e.g. Colias hyale, Aricia agestis and Polyommatus semiargus on meadow fallow land and Neozephyrus quercus, Thecla betulae and Pararge aegeria on forest fallow land).

\section{DISCUSSION}

The considerable number of 34 different butterfly species recorded in the study area, composed of vineyards and fallow land, show the typical pattern of relative abundance (Fig. 1, cf. Schmitt et al., 2002). Comparison with the managed semi-natural calcareous grassland reserves close to the study area, which had a maximum of 35 butterfly species per site in 2001 (Wenzel et al., 2006), reveals the regional importance of the butterfly diversity of this vineyard-fallow land mosaic landscape. This underlines the general conservation value of this type of agricultural landscape, especially as nine of the 34 species are in the regional Red Data Book (Bläsius et al., 1987) and eight species in the German Red Data Book (Pret- scher, 1998) (e.g. Aricia agestis, Coenonympha arcania, Polyommatus semiargus, Pyronia tithonus).

However, the differences in butterfly community structure between vineyards and fallow land are enormous with fallow land areas harbouring many more species, individuals and overall biodiversity (analysed by $S_{\mathrm{H}}$ and $\alpha$ ) than vineyards (Table 1). Three cumulative factors were most probably responsible for this: (i) vegetation was missing or very scarce in these vineyards (i.e. lack of nectar sources and larval food plants), (ii) the frequency of application of pesticides and herbicides might directly and indirectly have reduced butterfly populations in vineyards and at their margins and (iii) the very high human disturbance in these vineyards (e.g. numerous treatments during spring, summer and autumn) might have further lowered the abundance of the remaining butterflies. These findings are supported by other studies that indicate butterfly diversity in general decreases along gradients of increasing human disturbance (Yamamoto, 1977; Ruszczyk \& DeAraujo, 1992; Kitahara et al., 2000; Kitahara \& Sei, 2001; Schmitt, 2003).

TABLE 2. Means of species and individuals per transect, Shannon index $\left(S_{\mathrm{H}}\right)$, Alpha diversity $(\alpha)$, Evenness $\left(E_{\mathrm{S}}\right)$ and species dispersal ability (Bink, 1992) for meadow fallow land, forest fallow land and mixed fallow land transects (i.e. meadow on one and forest on the other side) in a vineyard-fallow land mosaic landscape in the vicinity of Trier (Germany). All means are given with their standard deviation. $p$ values refer to Kruskal-Wallis ANOVAs. A posteriori tests for significant differences between pairs of groups are calculated using $\mathrm{U}$ tests; different letters after the respective values indicate significant differences $(p<0.05)$.

\begin{tabular}{lcccc}
\hline & meadow & meadow/forest & forest & $p$ \\
\hline Species & $16.00 \pm 4.08^{\mathrm{a}}$ & $12.27 \pm 2.94^{\mathrm{a}}$ & $13.20 \pm 5.96^{\mathrm{a}}$ & 0.3080 \\
Individuals & $132.8 \pm 50.9^{\mathrm{a}}$ & $156.8 \pm 62.1^{\mathrm{a}}$ & $101.2 \pm 51.4^{\mathrm{a}}$ & 0.1839 \\
$S_{\mathrm{H}}$ & $0.921 \pm 0.091^{\mathrm{a}}$ & $0.771 \pm 0.103^{\mathrm{b}}$ & $0.797 \pm 0.256^{\mathrm{a}, \mathrm{b}}$ & 0.0441 \\
$\alpha$ & $4.85 \pm 1.37^{\mathrm{a}}$ & $3.19 \pm 0.83^{\mathrm{b}}$ & $4.16 \pm 1.98^{\mathrm{a}, \mathrm{b}}$ & 0.0650 \\
$E_{\mathrm{S}}$ & $0.776 \pm 0.063^{\mathrm{a}}$ & $0.715 \pm 0.060^{\mathrm{a}}$ & $0.738 \pm 0.102^{\mathrm{a}}$ & 0.2512 \\
Dispersal & $4.02 \pm 0.20^{\mathrm{a}}$ & $3.93 \pm 0.22^{\mathrm{a}}$ & $4.11 \pm 0.29^{\mathrm{a}}$ & 0.4835 \\
\hline
\end{tabular}


The average mobility of the species (applying the Bink (1992) scale) also differed strongly in our study area (Table 1). The highest average mobility was observed in the vineyards, the lowest on the fallow land areas, and vineyard margins had an intermediate position, but were not significantly different from vineyards. The almost complete absence of sedentary species in vineyards (but their presence on the fallow land) indicates that these species may not be able to survive in vineyards. Consequently, it is also likely that the great majority of the more mobile species (e.g. Papilio machaon, Pieris rapae, Vanessa atalanta, V. cardui) find vineyards unfavourable habitats (due to the lack of larval food plants and nectar sources) and migrate into vineyards from adjoining more suitable habitats. One exception might be Aricia agestis, whose larval food plant Erodium sp. (Schulte et al., 2007) was among the few common plant species present in the vineyards. The thermophilic Carcharodus alceae might be the only species that benefits from the existence of the vineyards because it is adapted to hot habitats with little vegetation cover (Ebert \& Rennwald, 1991; Schulte et al., 2007). Although this species was not recorded along the transects, it was exclusively observed in the vineyards. We therefore speculate that the vineyards represent nonhabitats for most butterfly species in our study area and may act as a sink for many dispersing individuals in this mosaic landscape (cf. Öckinger \& Smith, 2007b).

However, it is possible that the generalist species surviving in the vineyards simply have a greater dispersal capacity than the average of the species observed during our study. This possibility is ruled out by the fact that more than $95 \%$ of all individuals observed are not habitat specialists. Furthermore, of the four species whose larvae exclusively feed on Urtica, only the actively dispersing Vanessa atalanta, Aglais urticae and Inachis io were observed in the vineyards, but not the more sedentary Araschnia levana.

The vineyard margins are borders between fallow land areas and vineyards and have intermediate diversity parameters (Table 1, Fig. 2a). A negative effect of viticulture on the adjoining fallow land is evident and especially supported by (i) the intermediate dispersal values of the butterflies recorded in the vineyard margins differ significantly from those on the fallow land, but not in the vineyards and (ii) the mean number of individuals observed was more similar to the vineyards (mean difference: 46 individuals) than the fallow land areas (mean difference: 70 individuals). However, this negative effect cannot penetrate far into the fallow land areas; if so, the vineyard margins were almost similar in all their diversity parameters to the vineyards.

These findings have important conservation implications for the design and development of vineyard-fallow land mosaic landscapes, especially as the retraction of viticulture from steep and thus labour-intensive slopes is an ongoing process. The putative sink effect of the vineyards should be reduced as much as possible and the edge effects (i.e. the contact area with the vineyards and thus the perturbation due to pesticides and human disturbance) should be minimised. If these two assumptions hold true, fallow land areas and vineyards should be disentangled, and wherever possible the fallow land areas should consist of large continuous patches in order to avoid the negative effects of fragmentation (e.g. Thomas et al., 2001; Steffan-Dewenter \& Tscharntke, 2002; Tscharntke et al., 2002; Krauss et al., 2003; Henle et al., 2004; Piessens et al., 2005). There are two different strategies for attaining this goal: (i) selective abandonment of entire slopes with no fallow land on neighbouring slopes or (ii) a continuous strip of fallow land with a band of vineyards below or above.

The comparison of meadow and forest fallow land areas revealed that they differ in species composition (Fig. 2b), an effect frequently observed in comparative studies of different types of fallow land (Erhardt, 1985b; Beinlich, 1995; Balmer \& Erhardt, 2000). Thus, the conservation of a broad variety of different types of fallow land is necessary to maintain a high biodiversity in such types of landscapes.

As typical meadow fallow land areas turn into forest fallow land due to natural succession over a few decades (Böhmer, 1994; Bender \& Böhmer, 2000), and because the biodiversity of the meadow fallow land tends to be higher than that of forest fallow land (e.g. more species and higher mean $\alpha$ and $S_{\mathrm{H}}$ in our results), the long-term conservation of meadow fallow land areas is of special importance. We therefore suggest that meadow fallow land should be allowed to develop undisturbed until the appearance of the first bushes when such areas should be used e.g. as extensive sheep pasture (as in the case of some of the fallow land areas in this study) to prevent succession occurring. In no way, therefore, should meadow fallow land areas be artificially afforested as is often encouraged by local governments and practised by stakeholders.

If such vineyard-fallow land mosaic landscapes are developed as outlined above, this will preserve populations of many barren grassland plant and animal species. Consequently, the extinction risk of single populations will be relatively low, thus maintaining the viability of the respective metapopulations (Hanski, 1999).

ACKNOWLEDGMENT. We thank C. Jobelius, P. Lisiecki, A. Lückerath and S. Silber for field assistance and S. Burke (Stanford, CA, USA), D. Kime (La Fontaine, France), R. Didham (Christchurch, New Zealand) and R. Verovnik (Ljubljana, Slovenia) for helpful discussions on a draft version of this article and the correction of our English.

\section{REFERENCES}

Balmer O. \& ERhardt A. 2000: Consequences of succession on extensively grazed grasslands for Central European butterfly communities: rethinking conservation practices. Conserv. Biol. 14: 746-757.

BeINLICH B. 1995: Veränderungen der Wirbellosen-Zönosen auf Kalkmagerrasen im Verlaufe der Sukzession. Beih. Veröffentl. Natur Landschaftspfl. Baden-Württemberg 83: 283-310.

BENDER O. \& BÖHMER H.J. 2000: Kulturlandschaftswandel auf der Nördlichen Frankenalb. Fränkische Schweiz 2000: 29-32. 
BENTON T.G., ViCKERY J.A. \& WiLSON J.D. 2003: Farmland biodiversity: is heterogeneity the key? Trends Ecol. Evol. 35: 949-954.

BinK F.A. 1992: Ecologische Atlas van de Dagvlinders van Noordwest-Europa. Schuyt, Haarlem, 512 pp.

Bläsius R., Blum E., Fasel P., Forst M., Hasselbach W., KinKler H., Kraus W., Rodenkirchen J., Roesler R.-U., Schmitz W., Steffny H., Swoboda G., Weitzel M. \& Wipking W. 1987: Rote Liste der bestandsgefährdeten Schmetterlinge (Lepidoptera; Tagfalter, Spinnerartige, Eulen, Spanner) in Rheinland-Pfalz. Ministerium für Umwelt und Gesundheit, Mainz, 33 pp.

BÖHMER H.J. 1994: Die Halbtrockenrasen der Fränkischen Alb Strukturen, Prozesse, Erhaltung. Mitt. Fränk. Geogr. Ges. 41: 323-343.

Ebert G. \& Rennwald E. (eds) 1991: Die Schmetterlinge Baden-Württembergs. Vols 1 and 2. Eugen Ulmer, Stuttgart, 552 and $553 \mathrm{pp}$.

ERHARDT A. 1985a: Wiesen und Brachland als Lebensraum für Schmetterlinge: eine Fallstudie in Tavetsch (GR). Birkhäuser, Basel.

ERHARDT A. 1985b: Diurnal lepidoptera: sensitive indicators of cultivated and abandoned grassland. J. Appl. Ecol. 22: 849-861.

Gerken B. \& GöRner M. (eds) 2001: Neue Modelle zur Maßnahme der Landschaftsentwicklung mit großen Pflanzenfressern. Praktische Erfahrungen bei der Umsetzung. Natur und Kulturlandschaft 4, Universität Paderborn, Höxter.

Hanski I. 1999: Metapopulation Ecology. Oxford University Press, Oxford, $324 \mathrm{pp}$

Henle K., Davies K.F., Kleyer M., Margules C. \& Settele J. 2004: Predictors of species sensitivity to fragmentation. Biodiv. Conserv. 13: 207-251.

Hole D.G., Perkins A.J., Wilson J.D., Alexander I.H., Grice P.V. \& Evans A.D. 2005: Does organic farming benefit biodiversity? Biol. Conserv. 122: 113-130.

Karsholt O. \& RazowsKi J. (eds) 1996: The Lepidoptera of Europe. A distributional Checklist. Apollo Books, Stenstrup, $380 \mathrm{pp}$.

Kitahara M. \& Sei K. 2001: A comparison of the diversity and structure of butterfly communites in semi-natural and humanmodified grassland habitats at the foot of Mt. Fuji, central Japan. Biodiv. Conserv. 10: 331-351.

Kitahara M., Sei K. \& FujII K. 2000: Patterns in the structure of grassland butterfly communities along a gradient of human disturbance: further analysis based on the generalist/specialist concept. Popul. Ecol. 42: 135-144.

Krauss J., Steffan-Dewenter I. \& Tscharntke T. 2003: How does landscape context contribute to effects of habitat fragmentation on diversity and population density of butterflies? J. Biogeogr. 30: 889-900.

Lambshead P.J.D., Paterson G.L.J. \& Gage J.D. 1997: BioDiversity Professional Beta. The Natural History Museum \& The Scottish Association for Marine Science.

MaLICKY H. 1970: Untersuchungen über die Beziehungen zwischen Lebensraum, Wirtspflanze, Überwinterungsstadium, Einwanderungsalter und Herkunft mitteleuropaäischer Lycaenidae (Lepidoptera). Entomol. Abh. Staatl. Mus. Tierk. Dresden 36: 341-360.

ÖCKINGER E. \& SMith H.G. 2007a: Semi-natural grasslands as population sources for pollinating insects in agricultural landscapes. J. Appl. Ecol. 44: 50-59.

ÖCKINGER E. \& SMith H.G. 2007b: Asymmetric dispersal and survival indicate population sources for grassland butterflies in agricultural landscapes. Ecography 30: 288-298.
Piessens K., Honnay O. \& Hermy M. 2005: The role of fragment area and isolation in the conservation of heathland species. Biol. Conserv. 122: 61-69.

Pollard E. \& YATES T.J. 1993: Monitoring Butterflies for Ecology and Conservation. The British Butterfly Monitoring Scheme. Chapman \& Hall, London, 288 pp.

Ротт R. 1995: Die Pflanzengesellschaften Deutschlands. 2nd ed. UTB, Stuttgart, $427 \mathrm{pp}$.

Pöyry J., Lindgren S., Salminen J. \& KuUssaari M. 2005: Responses of butterfly and moth species to restored cattle grazing in semi-natural grasslands. Biol. Conserv. 122: 465-478.

Pretscher P. 1998: Rote Liste der Großschmetterlinge (Macrolepidoptera). In Binot M., Bless R., Boye P., Gruttke H. \& Pretscher P. (eds): Rote Liste gefährdeter Tiere Deutschlands. Schriftenreihe für Landschaftspflege und Naturschutz 55, Bonn, pp. 87-111.

RundlöF M. \& Sмith H.G. 2006: The effect of organic farming on butterfly diversity depends on landscape context. J. Appl. Ecol. 43: 1121-1127.

RuszczyK A. \& DeAraujo A.M. 1992: Gradients in butterfly species diversity in an urban area in Brasil. J. Lepid. Soc. 46: 255-264.

Schмiтt T. 2003: Influence of forest and grassland management on the diversity and conservation of butterflies and burnet moths (Lepidoptera: Papilionoidea, Hesperiidae, Zygaenidae). Anim. Biodiv. Conserv. 26.2: 51-67.

Schmitt T. \& RÁkosy L. 2007: Changes of traditional agrarian landscapes and their conservation implications: a case study of butterflies in Romania. Divers. Distrib. 13: 855-862.

Schmitt T., Lambracht E., Scheelke K., Tietze D.T. \& Seitz A. 2002: Wie viele Tagfalterarten gibt es in einem Habitat? Eine ökologische Fallstudie in Norditalien (Lepidoptera: Rhopalocera). Nachr. Entomol. Ver. Apollo 23: 1-6.

Schulte T., Eller O., Niehuis M., Rennwald E. (eds) 2007: Die Tagfalter der Pfalz. Vols 1, 2. GNOR-Eigenverlag, Landau, 592 and $340 \mathrm{pp}$

Settele J., Feldmann R. \& Reinhardt R. (eds) 1999: Die Tagfalter Deutschlands - Ein Handbuch für Freilandökologen, Umweltplaner und Naturschützer. Ulmer, Stuttgart, 452 pp.

Settele J., Steiner R., Reinhardt R. \& Feldmann R. (eds) 2005: Schmetterlinge Die Tagfalter Deutschlands. Ulmer, Stuttgart, $256 \mathrm{pp}$.

StefFan-Dewenter I. \& TscharntKe T. 2002: Insect communities and biotic interactions on fragmented calcareous grasslands - a mini review. Biol. Conserv. 104: 275-284.

Thomas J.A. \& Morris M.G. 1994: Patterns, mechanisms and rates of decline among UK invertebrates. Phil. Trans. R. Soc. Lond. (B) 344: 47-54.

Thomas J.A., Bourn N.A.D., Clarke R.T., Stewart K.E., Simcox D.J., Pearman G.S., Curtis R. \& Goodger B. 2001: The quality and isolation of habitat patches both determine where butterflies persist in fragmented landscapes. Proc. $R$. Soc. Lond. (B) 268: 1791-1796.

Thomas J.A., Telfer M.G., Roy D.B., Preston C.D., Greenwood J.J.D., Asher J., Fox R., Clarke R.T. \& Lawton J.H. 2004: Comparative losses of British butterflies, birds, and plants and global extinction crisis. Science 303: 1879-1881.

Tscharntke T., Steffan-Dewenter I., Kruess A. \& Thies C. 2002: Characteristics of insect populations on habitat fragments: A mini review. Ecol. Res. 17: 229-239.

van SwaAy C.A.M. 2002: The importance of calcareous grasslands for butterflies in Europe. Biol. Conserv. 104: 315-318.

van SwaAy C.A.M. \& Warren M. 1999: Red Data Book of European Butterflies (Rhopalocera). Nature and environment 99. Council of Europe Publishing, Strasbourg, 260 pp. 
VARGA Z. 2003a: Post-glacial dispersal strategies of Orthoptera and Lepidoptera in Europe and in the Carpathian basin. Proc. 13th Int. Col. Eur. Invert. Survey, Leiden, 2-5 September 2001. European Invertebrate Survey, Leiden, pp. 93-106.

VARGA Z. 2003b: Halbtrockenrasen im pannonischen Raum als Lebensräume schutzwürdiger Orthopteren- und Lepidopterengesellschaften. Ber. R. Tüxen Ges. 15: 115-167.

WallisDeVries M.F., Poschlod P. \& Willems J.H. 2002: Challenges for the conservation of calcareous grasslands in northwestern Europe: integrating the requirements of flora and fauna. Biol. Conserv. 104: 265-273.
WARREN M.S. 1993: A review of butterfly conservation in central southern Britain: II. Site management and habitat selection of key species. Biol. Conserv. 64: 37-49.

Weidemann H.-J. 1986: Tagfalter. Vol. 1. J. NeumannNeudamm, Melsungen, $282 \mathrm{pp}$.

Wenzel M., Schmitt T., Weitzel M. \& Seitz A. 2006: The severe decline of butterflies on western German calcareous grasslands during the last 30 years: A conservation problem. Biol. Conserv. 128: 542-552.

ҮАмамото M. 1977: A comparison of butterfly assemblages in and near Sapporo city, northern Japan. J. Fac. Sci. Hokkaido Univ. (Ser. 6, Zool.) 20: 621-646.

Received November 1, 2007; revised and accepted January 9, 2008 